Elizabeth Rankin and Rolf Michael Schneider

From Memory to Marble 


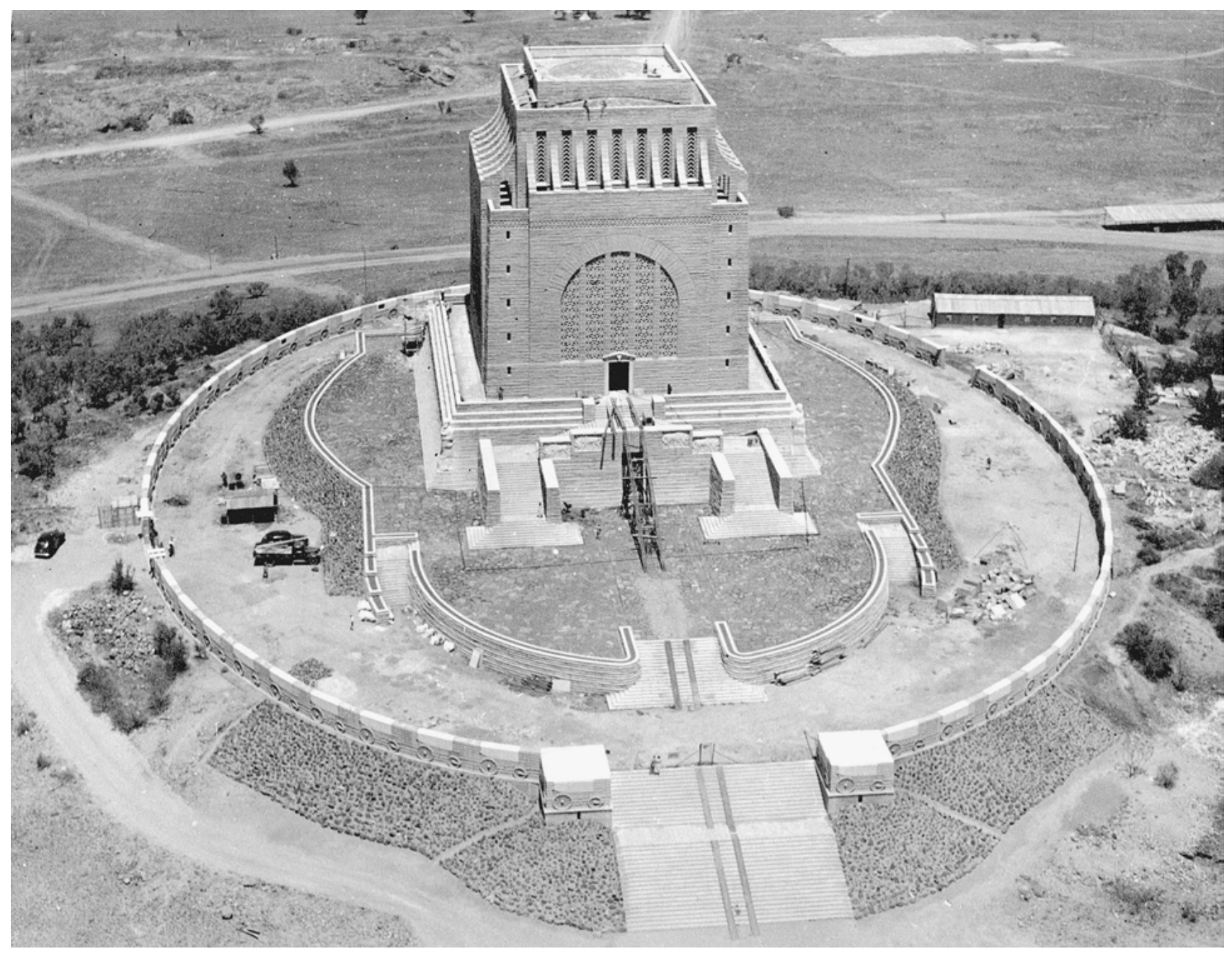

Aerial view of Voortrekker Monument in 1949: building site with ramps for transporting the completed marble panels into the Hall of Heroes (photo courtesy of Unisa Archives, Van Schaik album) 
Elizabeth Rankin and Rolf Michael Schneider

\section{From Memory to Marble}

The historical frieze of the Voortrekker Monument

Part I: The Frieze 
Published with the support of the Gerda Henkel Foundation, Duesseldorf

ISBN 978-3-11-061522-7

e-ISBN (PDF) 978-3-11-066878-0

e-ISBN (EPUB) 978-3-11-066904-6

\section{(cc) BY}

This work is licensed under a Creative Commons Attribution 4.0 License. https://creativecommons.org/licenses/by/4.0/

\section{Library of Congress Control Number: 2019951916}

Bibliographic information published by the Deutsche Nationalbibliothek

The Deutsche Nationalbibliothek lists this publication in the Deutsche Nationalbibliographie; detailed bibliographic data are available on the internet at http://dnb.dnb.de

(C) 2019 Walter de Gruyter GmbH, Berlin/Boston

Cover image: Voortrekker Monument, Hall of Heroes, east section of south frieze (courtesy of VTM; photo Russell Scott)

Typesetting: Satzstudio Borngräber, Dessau-Roßlau

Printing and Binding: Hubert \& Co. GmbH \& Co. KG, Göttingen

Printed in Germany

www.degruyter.com

www.africanminds.org.za 
For Angela and Peter 
From Memory to Marble is an open access monograph in the true sense of the word. Both volumes of the digital version of the book are available in full and free of charge from the date of publication. This approach to publishing democratises access to the latest scholarly publications across the globe. At the same time, a book such as From Memory to Marble, with its unique and exquisite photographs of the frieze as well as its wealth of reproduced archival materials, demands reception of a more traditional kind, that is, on the printed page. For this reason, the book is likewise available in print as two separate volumes. The printed and digital books should not be seen as separate incarnations; each brings its own advantages, working together to extend the reach and utility of From Memory to Marble to a range of interested readers.

François van Schalkwyk

African Minds 